\title{
STRATEGI KEPEMIMPINAN PEMBELAJARAN \\ MENYONGSONG IMPLEMENTASI KURIKULUM 2013
}

\author{
Husaini Usman dan Nuryadin Eko Raharjo \\ FT Universitas Negeri Yogyakarta \\ email: husainiusman@gmail.com
}

\begin{abstract}
Abstrak: Penelitian ini bertujuan untuk menemukan konsep strategi kepemimpinan pembelajaran. Perbedaan pembelajaran di SMK dengan SMA membawa konsekuensi strategi kepemimpinan pembelajaran yang berbeda pula. Penelitian menggunakan pendekatan kualitatif dengan jenis grounded theory. Instrumen penelitian adalah peneliti sendiri. Teknik pengumpulan data yang digunakan adalah wawancara mendalam, observasi partisipasi, dan dokumentasi. Subjek penelitian adalah kepala sekolah, wakil kepala sekolah, dan anggota komite sekolahsecara snowball. Orang kunci dalam penelitian ini adalah kepala sekolah. Objek penelitian adalah pelaku, konsep, tempat, dan kegiatan. Keabsahan data dilakukan dengan kriteria kredibilitas, transferabilitas, dependabilitas, dan komfirmabilitas. Langkah-langkah dan analisis data yang digunakan adalah model Lichman (2011). Penelitian menemukan bahwa strategi kepemimpinan pembelajaran adalah: keteladanan, pembelajaran di kelas dan luar kelas, kultur sekolah, dan penguatan.
\end{abstract}

Kata Kunci: strategi, kepemimpinan pembelajaran, implementasi kurikulum 2013

\section{THE STRATEGY OF INSTRUCTIONAL LEADERSHIP TOWARD THE IMPEMENTATION OF CURRICULUM 2013}

\begin{abstract}
Theresearch was aim to find the strategy concept of instructional leadership. Different between VHS and HS learning bring coonsequency different of strategy of instructional too. The research used was qualitative with grounded theory type. Research instrument is the researchers ourself. Data collecting technique were used deep-interview, participation observation, and documentation. Reseach subjects areprincipal, vice principals, and school committee members with snowball. Key informan is principal. Research objects are: persons, concept, place, and activities. Verification of data was done by credibility, transferability, dependability, and comfirmability criteria. Stage and data analysis were used the Lichman model (2011). The research findings that the strategy of instructional leaderships are modeling, learning in and out classroom, school culture, and strengthening.
\end{abstract}

Keywords: strategy, instructional leadership, implementation of curriculum 2013

\section{PENDAHULUAN}

Sekolah Menengah Kejuruan (SMK) sebagai penghasil tenaga kerja perlu memperhatikan keunggulan komparatif dan kompetitif. Keunggulan komparatif merupakan kemampuan dalam menghasilkan barang/jasa dengan biaya yang lebih hemat, mutu yang lebih hebat, dan waktu yang lebih tepat. Keunggulan kompetitif merupakan kemampuan daya saing lulusan SMK dalam tawar-menawar barang/jasa yang dihasilkannya di pasar kerja. Keunggulan kompetetif dapat pula dimaknai daya saing lulusan SMK dalam mendapatkan pekerjaan sebagai pekerja atau menciptakan lapangan kerja sebagai wirausaha karena tujuan SMK adalah untuk menghasilkan lulusan lulusan yang siap bekerja sesuai bidang keahliannya baik ikut bekerja dengan orang lain sebagai pekerja maupun berwirausaha. Penyebabnya antara lain kepala sekolah masih cenderung sebagai manager bukan sebagai leader pembelajaran. Akibatnya, ia lebih fokus pada urusan administratif dan sistem daripada urusan pemberdayaan guru untuk meningkatkan proses dan hasil pembelajaran siswa. Kepala sekolah yang efektif adalah kepala sekolah yang memiliki keseimbangan sebagai manager dan leader (Smith \& Piele, 2008). 
Masalah yang dihadapi SMK saat ini adalah belum ada konsep yang jelas tentang kepemimpinan pembelajaran dalam menyongsong implentasi Kurikulum 2013. Oleh sebab itu, kepemimpinan pembelajaran menyongsong implementasi Kurikulum 2013 perlu diteliti. Penelitian dengan judul tersebut sepengetahuan peneliti belum pernah dilakukan.

Model kepemimpinan ada sembilan yaitu: (1) manajerial; (2) partisipatif; (3) transformasional; (4) interpersonal; (5) transaksional; (6) postmodern; (7) kontingensi; (8) moral; dan (9) pembelajaran (intruksional). Pada penelitian ini dipilih kepemimpinan pembelajaran karena: relevan dengan bidang keahlian peneliti, komponen paling penting dalam meningkatkan mutu pembelajaran (Bush, 2008 \& Hammond, et al., 2010), faktor penting yang menentukan keefektifan sekolah (Huber, 2010), mengantisipasi tuntutan kompetensi kepala sekolah abad 21, mendukung keberhasilan implementasi Kurikulum 2013, kepemimpinan sekolah paling sukses jika difokuskan pada pembelajaran Leihwood \& Riehl (2008 \& Gurr; Drysdale, 2008), dan sukses atau gagalnya sekolah mencapai tujuan ditentukan oleh kepemimpinan kepala sekolahnya (Hoy \& Miskel, 2008; Bass \& Bass \& Huber, 2010). Tujuan penelitian ini adalah untuk menemukan konsep strategi kepemimpinan pembelajaran menyongsong implementasi Kurikulum 2013 di SMK sehingga kesenjangan kompetensi lulusan dengan dengan kompetensi yang dibutuhkan dunia kerja dapat dikurangi.

Strategi berasal dari bahasa Yunani, strategos. Strategos artinya tentara. Ago artinya memimpin. Strategi mula-mula digunakan di kemiliteran. Strategi adalah ilmu yang mempelajari perencanaan dan pengarahan operasi militer berskala besar dan menggerakkan pasukan pada posisi yang paling menguntungkan sebelum pertempuran sebenarnya dengan musuh untuk mendapat kemenangan.Istilah strategi bisnis dan perencanaan strategi di bidang manajemen muncul tahun 1950-an dan populer tahun 1960 sampai tahun 1970-an.

Ada 66 definisi strategi yang telah diidentifikasikan oleh Abraham (2004) dan ia menyimpulkan strategi adalah: berkaitan de- ngan berpikir strategi dan perencanaan strategi, penentu utama dalam berpikir strategi dan perencanaan strategi, metode untuk mendapatkan alternatif strategi, dan membantu pembaca dalam menggunakan keuangan dan analisis strategi berbagai alat.Strategi merupakan upaya yang sistematis melalui pengintegrasian dari tujuan, sasaran, kebijakan, program, dan kegiatan untuk mencapai misi Depdiknas yang telah ditetapkan (Rencana Strategi Pendidikan Nasional2010-2015). Pendapat-pendapat di atas dapat disimpulkan bahwa yang dimaksud dengan strategi adalah pendekatan umum bersifat jangka panjang untuk mempertahankan hidupnya suatu organisasi melalui meningkatkan daya saing secara berkelanjutan."Strategi selanjutnya dijabarkan menjadi pendekatan khusus jangka pendek atau langkah-langkah operasional yang disebut taktik.

Konsep kepemimpinan pembelajaran memiliki sejarah yang panjang, kompleks, dan multi-interpretasi tentang segala sesuatu yang harus dilakukan kepala sekolah Gurr \& Drysdale (2008).Pada tahun 1960, para kepala sekolah meningkatkan mutu pembelajaran dengan melakukan observasi ke kelas-kelas.Pada 1970 ketika Amerika Utara, Inggris, dan Australia menerapkan sistem inspeksi terhadap pembelajaran, peranan kepala sekolah sangat ditekankan.

Pada tahun 1970-an sampai awal 1980-an, buku teks administrasi pendidikan difokuskan pada supervisi. Beberapa literatur mengungkapkan bahwa supervisi dapat meningkatkan mutu pembelajaran di kelas.Kepala sekolah adalah orang yang paling bertanggung jawab terhadap kepemimpinan pembelajaran dan pengembangan kurikulum (Gurr \&Drysdale (2008). Sejak tahun 1970 definisi kepemimpinan pembelajaran masih membingungkan. Kepemimpinan pembelajaran mencapai puncaknya di Amerika Utara pada tahun 1980 dan fokus kepemimpinan pada peran kepala sekolah dalam kepemimpinan pembelajaran (Murphy, 1990).

Kerangka pikir kepemimpinan pembelajaran memiliki empat dimensi yaitu: (1) mengembangkan misi dan tujuan pembelajaran berdasarkan misi dan tujuan sekolah; (2) mengelo- 
la pembelajaran; (3) meningkatkan iklim pembelajaran; dan (4) mengembangkan dukungan lingkungan kerja (Murphy, 1990). Kepemimpinan pembelajaran di Indonesia mulai popular tahun 2010 ketika Direktorat Tenaga Kependidikan Ditjen Peningkatan Mutu Pendidik dan Tenaga Kependidikan mulai mengadakan pelatihan kepala sekolah. Kepemimpinan pembelajaran di Australia disebut educational leadership. Kepemimpinan pembelajaran (instructionnal leadership) disebut juga education leadership, school leadership, visionary leadership, and teaching, learningleadership, and supervision leadership (Huber, 2010).

Soutworth (2002) menyatakan kepemimpinan pembelajaran adalah perhatian yang kuat terhadap pengajaran dan pembelajaran, termasuk pembelajaran profesional oleh guru sesuai perkembangan siswa. Sejalan dengan pendapat Soutworth tersebut, Hallinger (2003) menyatakan bahwa kepemimpinan pembelajaran dipandang sebagai kepemimpinan direktif kepala sekolah yang kuat berfokus pada kurikulum dan pembelajaran. Sejalan dengan pendapat Southworth dan Hallinger di atas, Bush dan Glover (2003) menyatakan bahwa kepemimpinan pembelajaran fokus pada pengajaran dan pembelajaran serta perilaku guru dalam mengajar siswa. Pengaruh pemimpin ditargetkan pada pembelajaran siswa melalui guru. Penekanan langsung pada dampak pengaruh daripada proses itu sendiri. Ketiga pendapat tersebut dapat disimpulkan bahwa kepemimpinan pembelajaran adalah kepemimpinan yangfokus pada peningkatan mutu pembelajaran siswa melalui guru.

Kelemahan dari konsep kepemimpinan pembelajaran adalah terlalu berpusat pada kepala sekolah sehingga kepala sekolah cenderung otoriter dalam menerapkan kepemimpinannya. Sistem implementasi kurikulum 2013 memerlukan perubahan manajemen dan kepemimpinan, kultur dan iklim sekolah terhadap kurikulum, pendidik dan tenaga kependidikan, sarana dan prasarana untuk menghasilkan lulusan yang kompeten (Bahan Uji Publik Kurikulum 2013). Perubahan tersebut dipelopori oleh kepala sekolah karena kepala sekolah adalah agen perubahan.
Perbedaan pembelajaran di SMK dengan di SMA. Pembelajaran di SMK meliputi mata pelajaran wajib, pilihan, dan vokasi; sedangkan mata pelajaran di SMA meliputi mata pelajaran wajib dan pilihan. Perbedaan tersebut berdampak strategi kepemimpinan pembelajaran di SMK berbeda dengan kepemimpinan pembelajaran di SMA. Manajemen dan kepemimpinan, iklim akademik dan kultur sekolah merupakan salah satu faktor pendukung untuk meningkatkan efektivitas interaksi dalam strategi peningkatan efektivitas pembelajaran (Bahan Uji Publik Kurikulum 2013).

Strategi kepemimpinan pembelajaran yang ditemukan Southworth (2002) dalam penelitian dengan pendekatan kualitatifnya pada Kepala Sekolah Dasar di Inggris dan Wales ada tiga strategi untuk meningkatkan pembelajaran secara efektif yaitu: (1) modeling; (2) monitoring; dan (3) professional dialog and discussion. Modelling artinya keteladanan kepala sekolah menjadi contoh atau model yang ditiru oleh guru di sekolah yang dipimpinnya. Monitoring artinya melakukan pemantauan kinerja guru ke kelas saat guru melaksanakan proses pembelajaran di kelas serta memanfaatkan hasil pemantauan tersebut untuk pembinaan lebih lanjut. Professional dialog and discussion artinya berarti membicarakan secara aktif, interaktif, efektif, aspiratif, inspiratif, produktif, demokratik dan ilmiah tentang hasil penilaian kinerja dan rencana tindak lanjut peningkatan mutu proses dan hasil pembelajaran siswa.

Temuan penelitian Southworth (2002) tersebut mendukung kepemimpinan pembelajaran efektif apabila kepala sekolah mampu memainkan perannya sebagai: (1) pemantau kinerja guru; (2) penilai kinerja guru; (3) pelaksana dan pengaturan pendampingan dan pelatihan, (4) perencana Pengembangan Keprofesian Berkelanjutan (PKB) guru; (5) pengkoordinasi kerja tim, dan (6) pengkoordinasi pembelajaran kolaboratif (OECD, 2009).Sejalan dengan pendapat OECD tersebut, Willison (2008) menyatakan tiga cara untuk menjadi kepemimpinan pembelajaran efektif yaitu: (1) talk the talk; (2) walk the walk; dan (3) be the caddy. Talk to talk artinya banyak berdialog dan diskusi tentang pe- 
ngembangan keprofesian berkelanjutan guru. Walk the walkartinya sering berkunjung ke kelas memantau proses pembelajaran di kelas. $B e$ the caddy artinya membantu guru menggunakan sarana dan prasarana pembelajaran secara profesional.

\section{METODE}

Pendekatan penelitian yang digunakan dalam penelitian ini adalah kualitatif dengan jenis grounded theory. Jenis ini dipilih karena peneliti ingin menemukan konsep strategi kepemimpinan pembelajaran menyongsong implementasi kurikulum 2013 yang berakar dari data lapangan dan setelah dianalisis secara induktif menemukan strategi yang dimaksud.Instrumen penelitian adalah peneliti sendiri. Teknik sampel yang digunakan snowball sampling artinya responden bertambah terus dan tidak dapat ditetapkan jumlah sampai diperoleh data yang jenuh (redundancy). Instrumen penelitian adalah peneliti sendiri.

Teknik pengumpulan data menggunakan wawancara mendalam, observasi partisipasi, dan dokumentasi. Dalam pengumpulan data, prinsip yang ditekankan dalam penelitian kualitatif yang menjadi perhatian peneliti yakni: (1) prinsip emik dan etik-prinsip pengumpulan data secara objektif dengan lebih mengutamakan sudut pandang subjek, artinya penelitian mendeskripsikan ide, gagasan pemikiran atau pemikiran-pemikiran lain berdasarkan pemyataan subjek (prinsip emik). Namun demikian untuk kasus-kasus tertentu peneliti berusaha membuat penyimpulan dengan tanpa mengabaikan esensi makna fenomena (prinsip etik); (2) prinsip holistik-mengacu pada pengumpulan data yang utuh, lengkap dan kontekstual; (3) prinsip kekonsistenan- menyangkut konsistensi dalam hal sistem pengamatan, penentuan struktur penjelasan dan kode pengkategorian.

Subjek penelitian adalah kepala sekolah, wakil kepala sekolah, dan anggota komite sekolah. Orang kunci dalam penelitian ini adalah kepala sekolah. Objek penelitian adalah pelaku, konsep, tempat, dan kegiatan. Pelakunya adalah kepala sekolah, konsepnya adalah strategi kepemimpinan, tempatnya adalah SMKN 2 Depok
Sleman Yogyakarta. Kegiatannya adalah pembelajaran di dalam dan di luar kelas.

Sebelum melakukan penelitian, peneliti mengadakan studi pendahuluan untuk menjajaki bahwa sekolah tersebut layak sebagai tempat penelitian. Peneliti selalu menjaga jarak yaitu tidak terlalu akrab (hangat) dan juga tidak terlalu jauh (dingin) dengan subjek penelitian untuk mendapatkan objektivitas yang tinggi. Suasana penelitian diusahakan dalam suasana santai, tidak terlalu formal, dan kekeluargaan agar data yang didapat sedeskriptif mungkin.

Peneliti berusaha menjadi peneliti kualitatif seperti yang disarankan oleh Lichtman (2010) berikut. Saya: (1) tertarik pada orang dan empati kepadanya, kepada situasi dan lingkungannya; (2) tertarik pada orang dalam keadaan alamiah; (3) tertarik pada perilaku, pandangan, atau perasaan, karakteristik subjek yang diteliti; (4) senang dengan peluang menggali ide-ide subjek yang diteliti secara mendalam; (5) ingin menanyakan bagaimana manusia berinteraksi? bagaimana jaringan sosial dikembangkan?, dan bagaimana kultur dipelihara?; (6) mampu mempetimbangkan dengan bail dan melakukan instrospektif dengan baik pula; (7) senang dengan orang dan melihat bagaimana mereka merasakan; (8) memperhatikan semua yang mereka bicarakan, tentang yang mereka deskripsikan, dan tentang cara mereka bergaul; (9) tertarik dengan proses pembelajaran di kelas, (10) melihat nilai-nilai di balik fakta-fakta dan tabel-tabel; (11) tertarik dengan cara-cara baru mereka mengerjakan sesuatu secara inovatif; (12) pendengar yang baik dan penanya yang baik pula; (13) termotivasi dengan hal-hal yang mendua (ambiguity); (14) toleran terhadap kekakuan struktur; (15) senang menuliskan semua data yang relevan dengan tujuan penelitian; (16) pernah menulis laporan penelitian, tesis, dan disertasi; (17) ingin melihat hasil penelitian yang maknanya melebihi pengujian hipetesis; (18) terbuka terhadap ide-ide baru; dan (19) mengakui bahwa semua penelitian adalah kompleks, penuh tantangan, dan tidak menganggap mudah melakukannya.

Teknik pemeriksaan atau pengujian pada tingkat kepercayaan hasil sangat diperlukan 
untuk menentukan keabsahan data. Keabsahan data dilakukan dengan kriteria (1) kredibilitas; (2) transferabilitas; (3) dependabilitas; dan (4) komfirmabilitas atau kepastian (objektivitas). Langkah-langkah dan analisis data yang digunakan dalam penelitian ini adalah model Lichman (2011) seperti Gambar 1. Konsep strategi kepemimpinan pembelajaran menyongsong implementasi Kurikulum 2013 diproleh dengan langkah-langkah seperti Gambar 2.

\section{HASIL DAN PEMBAHASAN}

Hasil data yang dikumpulkan melalui wawancara mendalam, observasi partisipasi, dan dokumentasi tentang strategi pembelajaran meliputi empat kategori yaitu: (1) keteladanan; (2) pembelajaran di kelas dan di luar kelas; (3) kultur (budaya) sekolah; dan (4) penguatan.

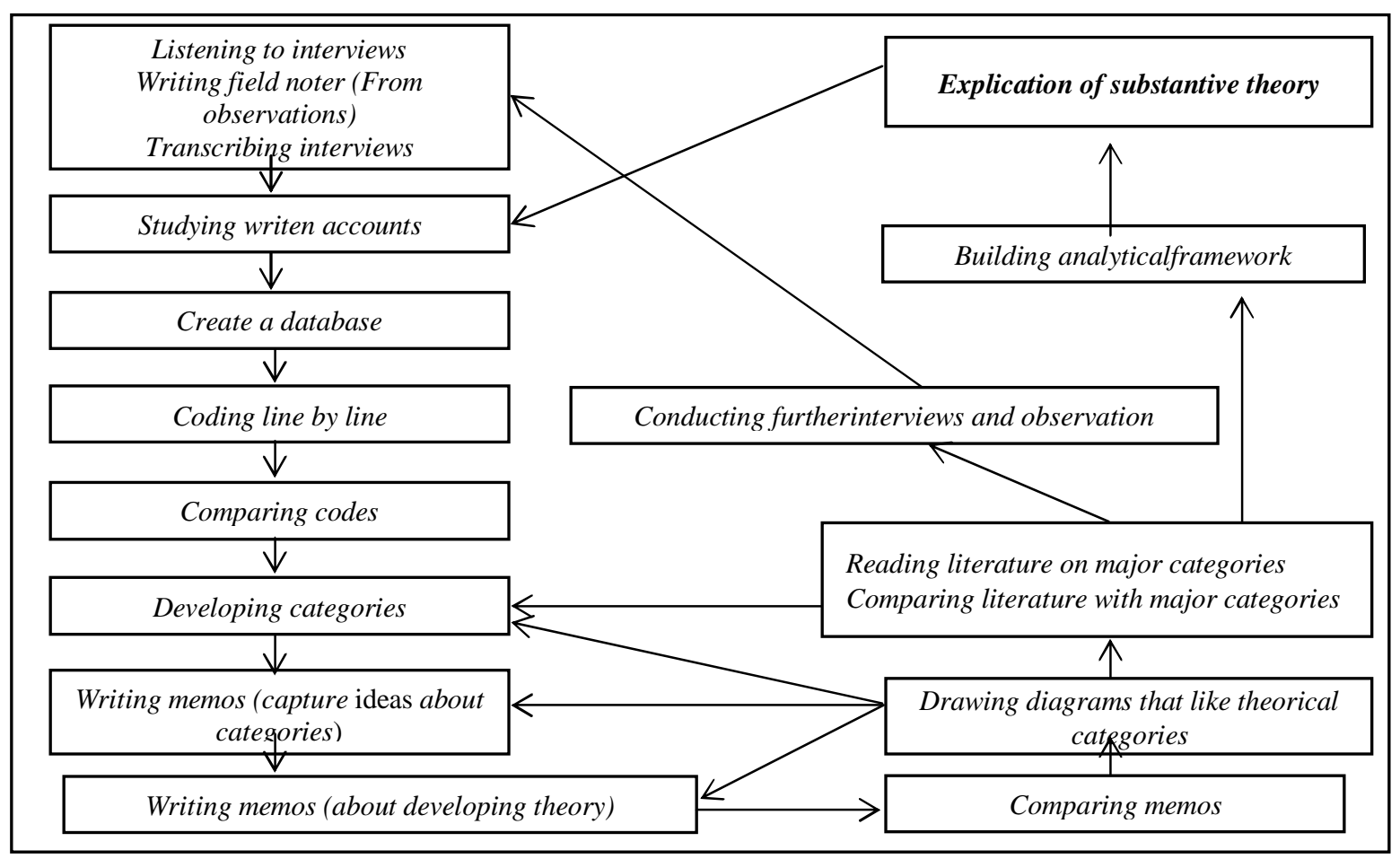

Gambar 1.Langkah dan Analisis Data (Lichman, 2011)

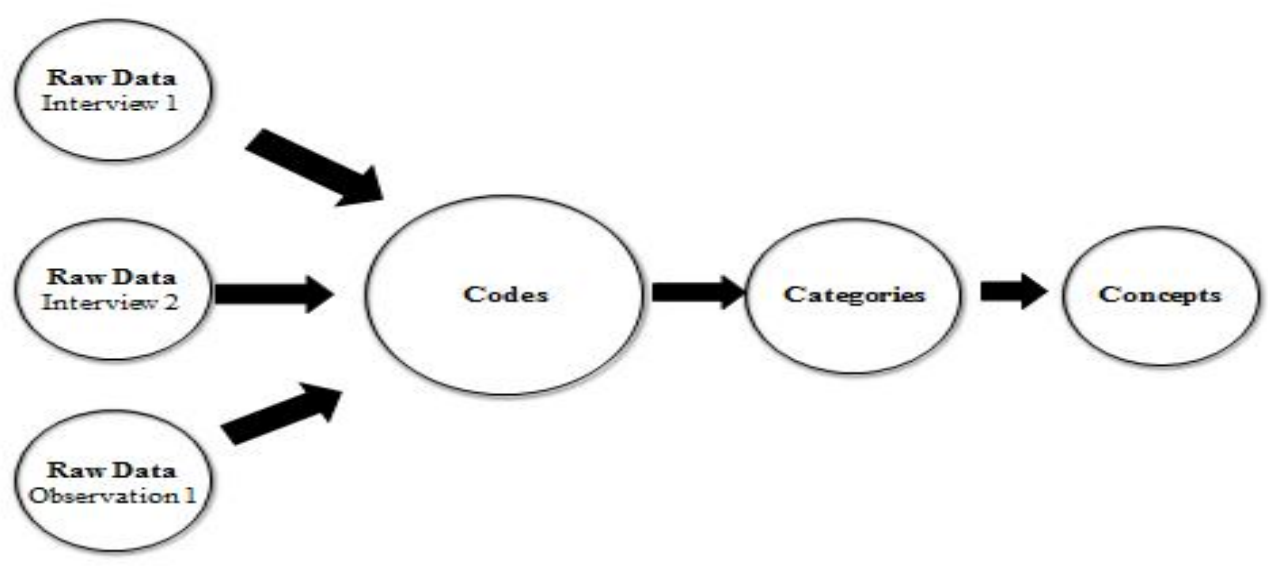

Gambar 2. Langkah Menemukan Konsep (Lichman, 2011) 


\section{Keteladanan}

Keteladanan adalah ucapan, bahasa tubuh, sikap, dan tindakan positif yang dapat dicontoh oleh orang lain. Keteladanan sebagai pemimpin pembelajaran antara lain ditunjukkan oleh gejala-gejala (fenomena) rutin yang tampak secara fisik yaitu: guru produktif dan karyawan jurusan bangunan menerima order pesanan seperti jasa perencanaan bangunan, guru produktif dan karyawan jurusan TKJ merakit laptop dan LCD dengan melibatkan siswa, guru produktif dan karyawan jurusan kimia menerima jasa tes laboratorium, guru produktif dan karyawan jurusan mesin menerima pemesanan $\mathrm{CNC}$, guruproduktif dan karyawan jurusan Geologi pertambangan menerima jasa sondir, guru produktif dan karyawan jurusan otomotif menerima jasa body repair mobil, guru produktif dan karyawan jurusan audio visual menerima pesanan barang-barang elektronika, memiliki komitmen dan tanggung jawab yang tinggi terhadap mutu proses dan hasil pembelajaran, memotivasi dan memfasilitasi guru untuk meningkatkan mutu proses dan hasil pembelajaran, memberi contoh yang baik dalam menyiapkan, melaksanan, dan menilai pembelajaran, sering berdialog dan berdiskusi dengan guru permasalahan mutu pembelajaran serta upaya penyelesaiannya.

Sering memantau proses pembelajaran di kelas dengan cara tidak mengganggu proses pembelajaran, memantau kinerja guru (mensupervisi guru), menilai kinerja guru, melaksanakan pengaturan pendampingan dan pelatihan, melaksanakan pengembangan keprofesian berkelanjutan guru, mengkoordinasi kerja tim, dan mengkoordinasikan pembelajaran kolaboratif, dan menjadikan unit produksi sekolah sebagai miniatur bisnis dan sumber belajar berwirausaha serta sebagai inkubator bisnis.

\section{Pembelajaran di Kelas dan di Luar Kelas}

Pembelajaran adalah kegiatan eksplorasi, elaborasi, dan konfirmasi untuk mentransformasikan, melestarikan, dan mengkritisi iptek dan kultur yang dilakukan di dalam dan di luar kelas. Pembelajaran di kelas antara lain ditunjukkan oleh gejala-gejala: pembelajaran dilak- sanakan melalui proses belajar setiap materi pelajaran ataukegiatan yang dirancang khusus. Setiap kegiatan belajar mengembangkan kemampuan dalam ranah kognitif,afektif, dan psikomotor.Pembelajaran di kelas yangkhusus menanamkan jiwa kewirausahaan adalah mata pelajaran kewirausahaan. Mata pelajaran yang memiliki kaitan erat dengan penanamanjiwa kewirausahaan adalah pelajaran di bidang produktif.

SMK bebas mengelola kurikulumnya, SMK menyusun kurikulumnya tanpa mempertimbangkan potensi sekolah, kebutuhan siswa dan kebutuhan lokal kabupaten/kota; kompetensi kewirausahaan belum relevan dengan dunia kerja, pelajaran praktik ada yang bersifat individual dan kelegial untuk memberikan pengalaman mampu bekerja sama dalam kerja tim; kompetensi kewirausahaan yang dibutuhkan dunia kerja, beban belajar relatif terlalu berat dan luas sehingga kurang mendalam, pembelajaran cenderung masih berpusat pada guru; pembelajaranmasihberorientasi buku teks; buku teks hanya memuat materi bahasan; penilaian hasilbelajar siswa masih cenderung bersifat kognitif; ujian keterampilan masih menggunakan ujian tertulis; proses pembelajaran masih terbatas pada eksplorasi, elaborasi, dan konfirmasi; belajar tidak hanya di dalam kelas, tetapi juga di lingkungan luar sekolah dan masyarakat; kompetensi keterampilan belum relevan dengan dunia kerja; penilaian belajar siswa masih pada hasil saja; forto folio yang dibuat siswa belum dimanfaatkan secara maksimal sebagai instrumen utama penilaian; guru masih cenderung sebagai satu-satunya sumber belajar; kewirausahaan masih diajarkan secara verbal (teoretis). Pembelajaran di dalam kelas ditunjukkan adanya kegiatan ekstra kurikuler seperti pramuka (belum wajib), organisasi kesiswaan, unit kesehatan sekolah, olahraga, kerawitan, teater, kaligrafi, pecinta alam, peleton inti dan KIR.

Pembelajaran di luar kelas dilaksanakan melalui kegiatankokurikuler dan ekstrakurikuler yang diikuti oleh sebagian siswa yang dimanfaatkan untuk mengembangkan jiwa kewirausahaan antara lain: pembuatan kaos identitas oleh siswa, siswa menjual makanan dan minuman 
yang dibeli oleh sesama siswa, guru, dan karyawan, yang dititipkan melalui koperasi siswa atau di ruang guru, kegiatan pendirian perusahaan di dalam sekolah bekerja sama dengan GE Lighting.

\section{Kultur Sekolah}

Kultur sekolah adalah keyakinan-keyakinan, nilai-nilai, norma-norma, tradisi bersama yang mengikat kebersamaan seluruh warga sekolah. Penciptaan kultur sekolah yang bernuansa kewirausahaan dilakukan melalui: penugasan, pembiasaan, pelatihan, pengajaran, pengarahan, dan keteladanan. Semuanya mempunyai pengaruh yang besar dalam pembentukan jiwa kewirausahaan siswa.Integrasi jiwa kewirausahaan ke dalam kultur sekolahdalam rangka pengembangan kultur kewirausahaan untuk masing-masing lapisan kultur sekolah adalah(1) integrasi jiwa kewirausahaan ke dalam kultur sekolah pada lapisan artifak; (2) integrasi jiwa kewirausahaan ke dalam kultur sekolah pada lapisan nilai-nilai dan keyakinan; (3) integrasi jiwa kewirausahaan ke dalam kultur sekolah pada lapisan asumsi dasar. Pada lapisan artifak ini terdapat tiga dimensi yang saling terkait yaitu: verbal, tingkah laku/behavioral,dan fisik/ material.

Nilai-nilai dan keyakinan kepala sekolah yang mewarnai kultur sekolah yang dapat mendukung pelaksanaan pendidikan kewirausahaan antara lain: Berani menanggung risiko, mampu bangkit dari kegagalan, mampu memanfaatkan semua sumberdaya seefektif mungkin, mampu mengembangkan sumberdaya yang ada, memiliki sifat dan sikap mental sebagai wirausaha, berpikir secara realistis, mampu melihat peluang, memiliki strategi pembelajaran bisnis, mampu membagi waktu dan materi tentang kewirausahaan.

Integrasi jiwa kewirausahaan ke dalam kultur sekolah adalah asumsi dasar,berupa petunjuk-petunjuk yang harus dipatuhi warga sekolah, menyangkut perilaku nyata termasuk menjelaskan kepada warga sekolah tentang cara merasakan dan memikirkan segala sesuatu. Asumsi dasar kewirausahaan: wirausaha bagian dari hidup dan setiap setiap lulusan SMKpasti "laku" di lapangan kerja.

\section{Penguatan}

Penguatan adalah usaha-usaha profesional yang dilakukan untuk meningkatkan mutu hasil dan proses pembelajaran di dalam dan di luar kelas.Penguatan antara lain ditunjukkan oleh gejala-gejala (fenomena) sebagai berikut.

Penguatan sebagai respon dari pendidikan kewirausahaan dilakukan dalam jangka panjang dan berulang terus-menerus. Penguatan dimulai dari lingkungan terdekat dan meluas pada lingkungan yang lebih luas. Di samping pembelajaran dan pemodelan, penguatan merupakan bagian dari proses intervensi. Penguatan juga dilakukan melalui proses habituasi dalam kultur sekolah. Hal itu akhirnya akan membentuk jiwa kewirausahaan yang terintegrasi melalui proses internalisasi dan personalisasi pada diri masingmasing individu warga sekolah.

Penguatan dapat dilakukan dalam berbagai bentuk termasuk penataan lingkungan belajar di sekolah yang menyentuh dan membangkitkan jiwa kewirausahaan. Berbagai penghargaan sudah diberikan kepada sekolah, pendidik, tenaga kependidikan, atau peserta didik untuk semakin menguatkan dorongan, ajakan, dan motivasi pengembangan jiwa kewirausahaan. Sementara itu dalam habituasi telah diciptakan penguatanyang memungkinkan peserta didik baik di sekolah, di rumahnya, di lingkungan masyarakatnya membiasakan diri berperilaku sesuai nilai dan menjadi karakter yang telah diinternalisasi dan dipersonalisai dari dan melalui proses intervensi.

Penguatan juga ditunjukkan oleh memberi pujian sewajarnya kepada siswa yang berprestasi akademik dan nonakademik, melakukan remedial terhadap siswa yang belum berprestasi, memberi tugas-tugas pekerjaan rumah secara individual dan kolegial dan hasilnya dikoreksi untuk dikembalikan kepada siswa yang bersangkutan, menambah referensi perpustakaan sekolah, memenuhi sarana dan prasarana yang langsung menunjang proses pembelajaran di kelas, melaksanakan Pengembangan Keprofesian Berkelanjutan (PKB) bagi guru seperti 
menggalakkan dialog professional dan diskusi ilmiah dalam Musyawarah Kelompok Kerja Guru (MKKG), mengadakan pelatihan, workshop, seminar, dan sejenisnya baik di dalam maupun di luar sekolah, memotivasi guru untuk studi lanjut sesuai dengan bidang keahliannya untuk meningkatkan pelaksanaan tugas sebagai guru profesional.

\section{PEMBAHASAN}

\section{Keteladanan}

Sebelum reformasi ada pemberian hadiah bagi guru teladan dan sekarang istilah berganti menjadi guru berprestasi, kepala sekolah berprestasi, dan pengawas berprestasi.Ada ungkapan, "Memberi contoh itu mudah, menjadi contoh itu susah."Artinya, memberi contoh itu bersifat insidentil sesuai kepentingan dan dibuatbuat, sedangkan menjadi contoh bersifat kebiasaan yang dilakukan secara berulang-ulang tanpa dibuat-dibuat dan tanpa kepentingan untuk dipuji dan mendapatkan hadiah.Kepala sekolah adalah sebagai "imam" di sekolah yang dipimpinnya. Oleh sebab itu, perilaku (pola pikir, sikap, tindakan) akan diikuti oleh guru sebagai "makmumnya". Sebaliknya, makmum wajib mengikuti imamnya selama imamnya tidak bersalah. Sebagai imam dan ilmuan, mau menerima krtik konstruktif dari makmumnya.

Temuan keteladanan sebagai strategi kepemimpinan pembelajaran mendukung kultur Indonesia yang cenderung patnernalistik. Orang tua dan orang-orang yang patut dihormati patut dicontoh keteladanannya. Temuan keteladanan ini mendukung strategi kepemimpinan pembelajaran yang diteliti Southworth (2002) dalam penelitian pendekatan kualitatifnya yang disebut modeling.

Dukungan itu terjadi karena adanya persamaan penelitian Southworth dengan penelitian ini. Persamaannya antara lain adalah samasama meneliti tentang strategi pembelajaran dengan pendekatan kualitatif. Perbedaan penelitian Southworth dengan penelitian ini antara lain adalah jika Soutworth meneliti kepemimpinan pembelajaran Kepala Sekolah Dasar kategori kecil Inggris dan Wales pada tahun 2002 dengan pengaruh kultur Barat dengan bentuk pe- merintahan kerajaan, maka penelitian ini meneliti, maka penelitian ini meneliti kepemimpinan Kepala SMK terbesar dan terkenal di Yogyakarta tahun 2012 dengan pengaruh kultur Jawa dengan bentuk pemerintahan republik.

\section{Pembelajaran di Kelas dan Luar kelas}

Temuan penelitian tentang pembelajaran di dalam dan di luar kelas mendukung pernyataan Soutworth (2002), Hallinger (2003), dan Bush \& Glover (2003) yang menyatakan kepemimpinan pembelajaran adalah kepemimpinan yang focus pada pembelajaran. Pembelajaran di sini meliputi pembelajaran di kelas dan di luar kelas.

Proses pembelajaran tidak hanya menyangkut eksplorasi, elaborasi, dan konfirmasi tetapi juga meningkatkan kompetensi siswa dalam melakukan observasi (menyimak, melihat, membaca, mendengar), bertanya, asosiasi, menyimpulkan, mengkomunikasikan baik secara lisan, tertulis, maupun bahasa tubuh) (Bahan Uji Publik Kurikulum 2013). Siswa sudah informasi ipetks dan kultur dari kelas dan luar kelas, dari guru, dari buku, dari berbagai sumber lainnya tetapi belum mampu meramunya dalam bentuk karya ilmiah. Kultur baca siswa kita masih rendah karena waktunya tersita oleh sinetron di tv, SMS, main game, melihat hal-hal yang tidak perlu di internet, dan berkomunikasi lewat telepon.

Siswa kita dapat dikatakan sebagai pendengar yang "baik" karena masih berkultur diam. Siswa takut bertanya pada hal belajar adalah bertanya karena ingin tahu. Kemampuan menyimpulkan masih rendah karena belum mampu menyimpulkan berbagai informasi.Siswa cenderung belum mampu mengkomunikasikan pikerannya baik secara tertulis, bahasa tubuh, mau pun lisan karena kurang menguasai substansi, dan bahasa Indonesia.

Kurikulum belum mempertimbangkan mempertimbangkan potensi sekolah, kebutuhan siswa dan kebutuhan lokal kabupaten/kota kurangnya wawasan guru dalam pengembangan kurikulum.Kompetensi kewirausahaan belum relevan dengan dunia kerja karena belum efektifnya kemitraan sekolah dengan dunia kerja. 
Pelajaran praktik ada yang bersifat individual dan kelegial untuk memberikan pengalaman mampu bekerja sama dalam kerja tim karena dunia kerja memutuhkan kerja tim yang solid.

Beban belajar relatif terlalu berat dan luas sehingga kurang mendalam akibatnya siswa banyak tahu sesuatu tetapi sedikit-sedikit. Pembelajaran cenderung masih berpusat pada guru karena guru belum mampu menerapkan PAKEM, pembelajaran kontekstual, dan pembelajaran kolaboratif secara efektif di samping masih kuatnya kultur diam di kalangan siswa kita. Pembelajaran masih berorientasi buku teks karena PAKEM, pembelajaran kontekstual, dan kolaboratif belum berjalan efektif.Penilaian sifat kognitif dan ujian keterampilan masih menggunakan ujian tertulis karena terbatasnya anggaran pendidikan. Proses pembelajaran masih terbatas pada eksplorasi, elaborasi, dan konfirmasi karena tidak ada tugas observasi, dan lainlain dari gurunya. Belajar tidak hanya di dalam kelas tetapi juga di lingkungan luar sekolah dan masyarakat karena belum diterapkannya pembelajaran kontekstual dan kolaboratif secara efektif.

Kompetensi keterampilan belum relevan dengan dunia kerja karena belum efektifnya kemitraan sekolah dengan dunia kerja. Penilaian belajar siswa masih pada hasil saja karena untuk mengejar target Ujian Sekolah dan Ujian Nasional yang bersifat tertulis. Forto folio yang dibuat siswa belum dimanfaatkan secara maksimal sebagai instrumen utama penilaian karena guru jarang memberi tugas untuk forto folio. Guru masih cenderung sebagai satu-satunya sumber belajar karena belum menerapkan PAIKEM, pembelajaran kontekstual dan kolaboratif secara efektif. Kewirausahaan masih diajarkan secara verbal (teoretis) karena guru-guru masih kurang pengalaman berwirausaha dan kurang efektifnya kemitraan dengan dunia kerja. Pembelajaran di dalam kelas ditunjukkan adanya kegiatan ekstra kurikuler seperti pramuka (belum wajib), Organisasi Kesiswaan, Unit Kesehatan Sekolah, dan PMR karena baru inilah kemampuan yang dimiliki sekolah.

Temuan pembelajaran di kelas dan di luar kelas ini bertentangan dengan Bahan Uji
Publik Kurikulum 2013.Pertentangan itu terjadi karena implementasi Kurikulum memerlukan perubahan-perubahan antara lain: standar proses yang semula terfokus pada eksplorasi, elaborasi, dan konfirmasi dilengkapi dengan mengamati, menanya, mengolah, menalar, menyajikan, menyimpulkan, dan mencipta, belajar tidak hanya terjadi di ruang kelas, tetapi juga di lingkungan sekolah dan masyarakat, guru bukan satu-satunya sumber belajar, sikap tidak diajarkan secara verbal, tetapi melalui contoh dan teladan, persamaan dari elemen penilaian adalah: penilaian berbasis kompetensi, pergeseran dari penilain melalui tes (mengukur kompetensi pengetahuan berdasarkan hasil saja], menuju penilaian otentik [mengukur semua kompetensi sikap, keterampilan, dan pengetahuan berdasarkan proses dan hasil], memperkuat PAP (Penilaian Acuan Patokan) yaitu pencapaian hasil belajar didasarkan pada posisi skor yang diperolehnya terhadap skor ideal (maksimal), penilaian tidak hanya pada level Kompetensi Dasar, tetapi juga kompetensi inti dan Standar Kompetensi Lulusan, mendorong pemanfaatan portofolio yang dibuat siswa sebagai instrumen utama penilaian, dan persamaan dalam Standar Kompetensi Lulusan (SKL) yang meliputi sikap, keterampilan, dan pengetahuan.

\section{Kultur Sekolah}

Kultur sekolah merupakan salah satu strategi kepemimpinan pembelajaran yang menjadi temuan penelitian ini. Dalam kultur sekolah sebenarnya sudah termasuk iklim sekolah seperti yang dinyatakan Schein (1997) bahwa ruang lingkup kultur sekolah adalah: tingkah laku yang diamalkan, bahasa, adat, tradisi, norma kelompok, standard dan nilai, dalam hal ini adalah kultur kewirausahaan, karya-karya yang dipublikasikan, falsafah formal, misi, aturan main, aturan untuk semua orang dalam organisasi, iklim sekolah, keterampilan tersembunyi, kebiasaan berpikir, paradigma, pengetahuan bersama untuk diketahui, makna bersama dalam kelompok, dan bahasa kiasan atau simbol-simbol. Beda kultur sekolah dengan budaya sekolah adalah kultur sekolah berakar dari antropologi, sedangkan iklim sekolah berakar dari so- 
siologi.Kultur SMK temuan penelitian ini adalah kultur kewirausahaan. Kultur kewirausahaan diperlukan di SMK karena tujuan SMK adalah untuk menyiapkan lulusan yang mampu bekerja sesuai bidangnya baik sebagai pekerja ikut orang lain mau pun sebagai wirausaha.

Kultur kewirausahaan temuan penelitian ini adalah berani menanggung risiko, mampu bangkit dari kegagalan ulet atau pantang menyerah), mampu memanfaatkan semua sumberdaya seefektif mungkin, mampu mengembangkan sumberdaya yang ada, memiliki sifat dan sikap mental sebagai wirausaha, berpikir secara realistis, mampu melihat peluang, memiliki strategi pembelajaran bisnis, mampu membagi waktu dan materi tentang kewirausahaan.Sifat kewirausahaan temuan penelitian ini masih sangat umum. Ada sifat-sifat penting yang harus dimiliki setiap wirausaha yaitu: jujur, kreatif, inovatif, kerja keras, motivasi berprestasi, pemasar ulung, komunikatif, negosiatif, hemat, energik, empati, etis, inisiatif, anthusias, dan visioner (Anonim, 2005).

Ki Hajar Dewantara (1928) menyatakan bahwa kultur adalah cipta, karsa, dan karya atau pikiran, perasaan, dan tindakan. Anonim (2005) lebih lanjut menjelaskan bahwa seorang wirausaha yang sukses harus memiliki kultur kewirausahaan. Pikiran, persaan, dan tindakan saling berkaitan seperti Gambar 3.
Jadi, kultur juga dapat dimaknai tentang kebiasaan cara manusia berpikir, berpersaan, dan bertindak. Pikiran adalah kumpulan informasi dan pertanyaan yang disimpan di otak dan dapat dipanggil jika dibutuhkan.Tindakan adalah keterampilan menerapkan pikiran.Perasaan adalah sekumpulan kualitas sifat yang membentuk kepribadian seseorang. Seseorang yang tidak memiliki budaya kewirausahaan tersebut akan gagal sebagai wirausaha yang sukses.

Temuan budaya kewirausahaan sebagai salah satu strategi kepemimpinan pembelajaran mendukung Pusat Pengembangan Kurikulum dan Perbukuan (2010) yang menyatakan bahwa kebajikan terdiri atas sejumlah nilai, moral, dan norma, seperti jujur, berani bertindak, dapat dipercaya, dan hormat kepada orang lain. Interaksi seseorang dengan orang lain menumbuhkan karakter masyarakat dan karakter bangsa. Oleh karena itu, pengembangan jiwa kewirausahaan hanya dapat dilakukan melalui pengembangan karakter individu seseorang. Akan tetapi, karena manusia hidup dalam lingkungan sosial dan kulturtertentu, maka pengembangan sifat-sifat individu seseorang hanya dapat dilakukan dalam lingkungan sosial dan kultur yang bersangkutan. Artinya, pengembangan kultur kewirausahaan hanya dapat dilakukan dalam suatu proses pendidikan yang tidak melepaskan siswa dari lingkungan sosial, kultur sekolahdan masyarakat.

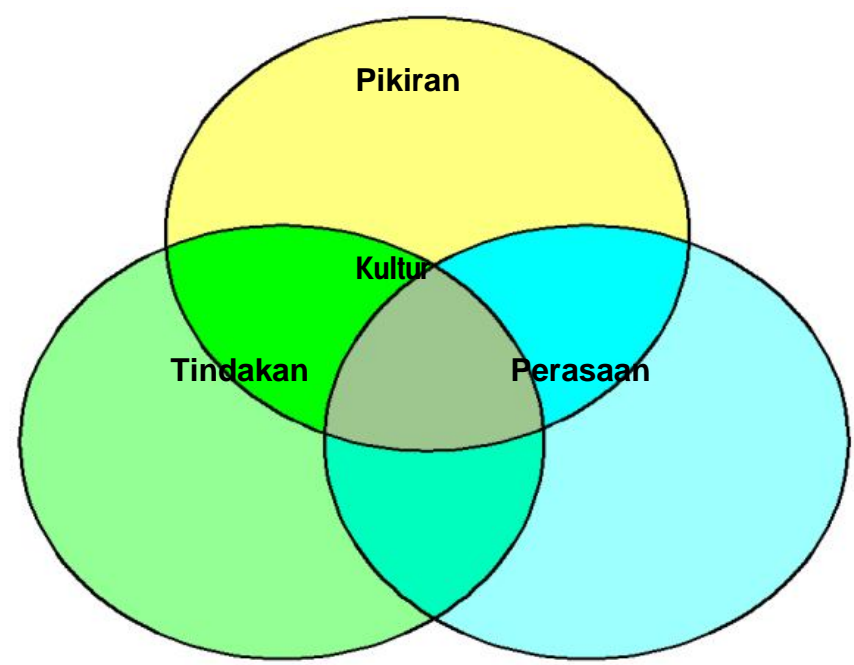

Gambar 3. Kultur Kewirausahaan 


\section{Penguatan}

Penguatan merupakan salah satu temuan strategi kepemimpinan pembelajaran.

Temuan penelitian ini mendukung hasil penelitian Southworth (2002) yang menemukan bahwa strategi kemimpinan pembelajaran untuk meningkatkan pembelajaran secara efektif yaitu: (1) modeling; (2) monitoring; dan (3) professional dialog and discussion. Adanya dukungan tersebut terjadi karena salah satu upaya untuk melaksanakan penguatan terhadap guru adalah dengan cara melakukan pemantauan ke kelas-kelas dan memantau kinerja guru secara terus-menurus. Selain itu, kepala sekolah harus mengadakan dialog professional dan diskusi dengan guru secara priodik untuk membahas tentang peningkatan mutu proses dan hasil pembelajaran siswa.

Temuan penguatan pendidikan kewirausahaan dalam penelitian ini mendukung pendapat Bubb \& Earley (2008) yang menyatakan bahwa pengembangan keprofesian kepala sekolah berkelanjutan adalah pelatihan profesional, pendidikan profesional, dan dukungan professional. PeContoh pelatihan profesional adalah kursus singkat, workshop, konfrensi, dan kegiatan lain yang lebih menekankan pada keterampilan. Contoh pendidikan profesional adalah kursus jangka panjang, studi lanjut yang menekankan pada pengetahuan, dan pengetahuan berbasis penelitian.Contoh dukungan profesional adalah kegiatan yang menekankan pada peningkatan pengalaman kerja dan kinerja (Bolam, 1993).Kegiatan pengembangan keprofesian kepala sekolah berkelanjutan dapat pula berupa kegiatan mengikuti pelatihan, mengikuti bimbingan teknis, mengikuti kursus, mengikuti seminar, belajar mandiri, dan membuat karya tulis ilmiah, dan mempublikasikan karya tulis ilmiah.

Pengembangan keprofesian kepala sekolah berkelanjutan adalah kegiatan yang mengarah pada seluruh pembelajaran formal dan informal yang mampu meningkatkan kepala sekolah dan guru melaksanakan tugas pokok dan fungsinya (Bubb \& Earley, 2007). Adanya program pengembangan keprofesian kepala sekolah dan guru diharapkan akan mampu meningkatkan kompetensinya secara berkelanjutan dalam rangka melaksanakan tugas pokok dan fungsinya sesuai dengan yang diharapkan.
Penguatan pendidikan kewirausahaan temuan penelitian ini tampaknya sudah layak dan praktis untuk dilaksanakan di sekolah dengan cara dimulai dari lingkungan sekolah dan meluas menjadi di luar lingkungan sekolah, pemodelan, intervensi, habituasi dalam kultur sekolah, terintegrasi, internalisasi, personalisasi, penataan lingkungan belajar di sekolah, memberi penghargaan, mendorong, mengajak, memotivasi, memberi pujian sewajarnya kepada siswa yang berprestasi akademik dan nonakademik, melakukan remedial terhadap siswa yang belum berprestasi, memberi tugas-tugas pekerjaan rumah secara individual dan kolegial dan hasilnya dikoreksi untuk dikembalikan kepada siswa yang bersangkutan, menambah referensi perpustakaan sekolah, memenuhi sarana dan prasarana yang langsung menunjang proses pembelajaran di kelas, melaksanakan Pengembangan Keprofesian Berkelanjutan (PKB) bagi guru seperti menggalakkan dialog profesional dan diskusi ilmiah dalam Musyawarah Kelompok Kerja Guru (MKKG), mengadakan pelatihan, workshop, seminar, dan sejenisnya baik di dalam maupun di luar sekolah, memotivasi guru untuk studi lanjut sesuai dengan bidang keahliannya untuk meningkatkan pelaksanaan tugas sebagai guru profesional.Penguatan profesional bagi kepala sekolah dan guru hanya mungkin terjadi secara efektif, jika kepala sekolah dan guru dengan penuh kesadaran untuk belajar sepanjang hayat dan mau membelajakan tujangan sertifikasi gurunya untuk meningkatkan profesionalnya melalui belajar mandiri, mengadakan pelatihan dan sejenisnya, bahkan studi lanjut.

\section{PENUTUP}

\section{Kesimpulan}

Konsep strategi kepemimpinan pembelajaran menyongsong implentasi Kurikulum 2013 meliputi empat kategori yaituketeladanan, pembelajaran dikelas dan luar kelas, kultur sekolah, dan penguatan.Keteladanan adalah ucapan, bahasa tubuh, sikap, dan tindakan positif yang dapat dicontoh oleh orang lain.Pembelajaran adalah kegiatan eksplorasi, elaborasi, dan konfirmasi untuk mentransformasikan, melestarikan, dan mengkritisi iptek dan kultur yang dilakukan 
di dalam dan di luar kelas. Kultur sekolah adalahkeyakinan-keyakinan, nilai-nilai, norma-norma, tradisi bersama yang mengikat kebersamaan seluruh warga sekolah. Kultur SMK adalah kultur kewirausahaan. Penguatan adalah usahausaha profesional yang dilakukan seseorang atau melalui orang lain untuk meningkatkan mutu hasil dan proses pembelajaran di dalam dan diluarkelas. Strategi kepemimpinan pembelajaran saat ini belum sepenuhnya mendukung implementasi Kurikulum 2013.

\section{Saran}

Saran untuk kepala sekolah.Implementasi Kurikulum 2013 menuntut perubahan kepemimpinan dan manajemen sekolah (kesiswaaan, sarana prasarana, keuangan, kelas, pembelajaran, pendidik dan tenaga kependidikan), iklim akademik, dan kultur sekolah. Oleh sebab itu, kepala sebagai agen perubahan sebaiknya mengubah diri bukan hanya sebagai manageryang sibuk menangani sistem sekolah tetapi juga sebagai leaderyang sibuk menangani guru melalui kepemimpinan pembelajaran dengan cara melaksanakan PKB. PKB tidak hanya mengandalkan biaya dari pemerintah tetapi biaya sendiri dengan menggunakan sebagian dari tujangan sertifikasi guru.

Saran untuk Kepala Dinas Pendidikan Kabupaten/Kota dan Kasubdit Pendidik dan Tenaga Kependidikan Pendidikan Menengah Direktorat Pendidikan Pembinaan Pendidik dan Tenaga Kependidikan Direktorat Jenderal Pendidikan Menengah Kementerian Pendidikan dan Kebudayaan hendaknya memfasilitasi Kepala SMK dan guru untuk mengadakan pelatihan atau bimbingan teknik antara lain pelatihan manajemen perubahan, manajemen kelas, manajemen pembelajaran, manajemen kesiswaan khususnya peminatan siswa, kepemimpinan pembelajaran, manajemen keuangan, manajemen sarana dan prasarana, dan manajemen pendidik dan tenaga kependidikan, manajemen kurikulum, administrasi persuratan dan pengarsipan berbasis ICT, sistem informasi manajemen sekolah berbasis ICT. Semua materi berbasis implementasi Kurikulum 2013, Materi hendaknya yang lebih mengutamakan praktik daripada teori sehingga banyak kasus dan simulasinya. Khusus untuk materi pelatihan Kepemimpinan pembelajaran disarankan menggunakan model OECD dengan berbagai modifikasi yang sesuai dengan kultur dan kemampuan sekolah di Indonesia.

\section{UCAPAN TERIMA KASIH}

Penulis mengucapkan terima kasih kepada redaksi, staf, dan mitra bestari Cakrawala Pendidikan yang telah memfasilitasi penerbitan artikel ini. Tanpa bantuan mereka mustahil artikel ini dapat diterbitkan.

\section{DAFTAR PUSTAKA}

Abraham, C.S. 2004. Strategic Planning A Practical Guide for Competitive Success. Canada: Thomson South Western.

Anonim. 2005. Mari Belajar Bisnis. Pendidikan Kewirausahaan untuk Sekolah Menengah Kejuruan dan Lembaga Pendidikan dan Pelatihan. Turino, Italy: International Training Centre, ILO.

Bass, M. \& Bass, R. 2008. The Bass Handbook of Leadership Theory, Research, \& Managerial Applications. Fourth Edition. New York: Free Press.

Bolam, R. 1993. "Recent Development and Emerging Issues" in The Continuing Professional Development of Teachers.London: GTC.

Bubb, S., \& Earley. 2008. Leading and Managing Continuing Prossional Development. London: Paul Chapman Publishing.

Bush, T. \& Glover, D. 2003. School Leadership: Concept and Evidence. Nottingham: National College for School Leadership.

Dempster, N., Lovett, S., \& Flukiger, B. 2011. "Strategies toDevelopschool Leadership". dalam A Select Literature Revieuw. Melbourne, Australia. Juli, page 1-35.

Depdiknas. 2010. Rencana Staregis Departemen Pendidikan Nasional 2010-2015. Ja- 
karta: Departemen Pendidikan Nasional. Jakarta.

Gurr, D., \&Drysdale, L. 2008. Instructional Leadership in Three Australian Schools. Melbourne, Australia: Centre for Organisational Learning and Leadership, The University of Melbourne.

Hallinger,P.2003. "LeadingEducationalChange: Reflections on the Practice of Instructional and Transformational Leadership", dalam Cambridge Journal of Education Vol. 33, No. 3, November, p. 35-70.

Hammond, L. D., Meyerson D., LaPointe, M., \& Orr, T. M. 2010.Preparing Principals for Changing World Lesson from Effective School Leadership Programs. San Francisco: Jossey-Bass.

Huber, G. S. 2010. School Leadership International Perspective. London: Springer.

Hoy, W.K., \& Miskel, C.G. 2008. Administration Education Theory, Research, and Practice. New York: Random House, Inc.

Kemdikbud. 2013. Bahan Uji Publik Kurikulum 2013. Jakarta: Kementerian Pendidikan dan Kebudayaan.

Leithwood, K.A. \& Riehl, 2008."What do We Already Know about Successful School Leadership?" dalam AERA Paper Task Force on Developing Research in Educational Leadership, page: 1-40.

Lichman, M. 2010. Qualitative Research in Education A User's Guide. Edition 2. London: Sage Publication, Ltd.
Lichman, M. (Editor). 2011. Understanding and Evaluating Qualitative Education Research. London: Sage Publication, Ltd.

Murphy, J. 1990. "Principal Instructional Leadership", dalam Advances in Educational Administration: Changing Perspectives on the School, 1, 163-200

Pusat Pengembangan Kurikulum dan Perbukuan. 2010. Pedoman Pelaksanaan Pendidikan Karakter. Jakarta: Pusat Pengembangan Kurikulum dan Perbukuan Badan Penelitian dan Pengembangan Kementerian Pendidikan Nasional.

Schein, E.H. 1997. Organizational Culture and Leadership. San Francisco: Jossey-Bass Publishers.

Smith, C.S., \& Piele, P.K. 2008.School Leadership Handbook for Excellent in Student Learning. FourthEdition. Thousand Oaks, California: Corwin Press A Sage Publication Company.

Soutworth, G. 2002. "Instructional Leadership in Schools: Reflection and Empirical Evidence", dalam School Leadership and Management. 22 (1): 73-92.

OECD. 2009. Improving Educational Leadership. Tool Kit.

Willison, R. 2010. "What Make an Instructional Leader", dalam Phi Delta Kappan, November 2010 Vol. 92 Nomor 3. page6669. 